\title{
Quantitative and Comparative Contents of Nitrate and Nitrite in Beta vulgaris L. by Reversed-Phase High-Performance Liquid Chromatography-Fluorescence
}

\author{
Diego dos Santos Baião ${ }^{1}$ - Carlos Adam Conte-Junior ${ }^{2}$ • \\ Vânia Margaret Flosi Paschoalin ${ }^{1}$ • Thiago Silveira Alvares ${ }^{1,3}$
}

Received: 30 March 2015 / Accepted: 6 August 2015 /Published online: 14 August 2015

(C) The Author(s) 2015. This article is published with open access at Springerlink.com

\begin{abstract}
The consumption of beetroot, a food rich in nitrate, has been recommended to enhance blood perfusion, restore endothelial function, and improve exercise performance. These properties may be explained by the possible effect of nitrate present in beetroot in stimulating the endogenous synthesis of nitric oxide, a potent vasodilator. However, there is limited evidence giving detailed information about how nitrate contents from beetroot used in studies have been analyzed. The purpose of this study was to evaluate nitrate and nitrite contents of beetroot from different regions of Brazil and from the USA. Nitrate and nitrite contents were quantified by using a reversed-phase high-performance liquid chromatography system with fluorescence detection. Beetroots from the USA showed the highest nitrate $\left(31.2 \pm 0.010 \mathrm{mmol} . \mathrm{L}^{-1}\right)$ and nitrite $\left(0.45 \pm 0.005 \mathrm{mmol} . \mathrm{L}^{-1}\right)$ contents when compared to beetroots from Brazil. Rio de Janeiro was the region that showed the highest nitrate content $\left(17.1 \pm 0.020 \mathrm{mmol} . \mathrm{L}^{-1}\right)$, while Rio Grande do Norte presented the highest nitrite content $\left(0.13 \pm 0.010 \mathrm{mmol} . \mathrm{L}^{-1}\right)$. The reversed-phase high-performance liquid chromatography-fluorescence method may be applied for the quantification of nitrate and nitrite contents in beetroot samples. The results of the present study demonstrate that beetroots may vary in their nitrate and nitrite contents.
\end{abstract}

Diego dos Santos Baião

diegobaiao20@hotmail.com

1 Departamento de Bioquímica, Instituto de Química, Universidade Federal do Rio de Janeiro, Av. Athos da Silveira 149, Cidade Universitária, Rio de Janeiro, Brazil

2 Departamento de Tecnologia de Alimentos, Universidade Federal Fluminense, Niterói, Brazil

3 Instituto de Nutrição, Universidade Federal do Rio de Janeiro, Macaé, Brazil
This data represents a useful tool to encourage researchers to analyze the nitrate and nitrite contents in beetroots utilized in interventional clinical studies.

Keywords Food composition $\cdot$ Beetroot $\cdot$ High-performance liquid chromatography $\cdot$ Nitrate $\cdot$ Nitrite

\section{Introduction}

Beetroots belonging to the Beta vulgaris L. species are considered a source of fibers, antioxidants, minerals, and carbohydrates. In addition, the vegetable is also considered a dietary $\mathrm{NO}_{3}{ }^{-}$source (Pennington 1998; Santamaría 2006; Tamme et al. 2006). The $\mathrm{NO}_{3}{ }^{-}$content in this food matrix has been proposed to enhance blood perfusion (Webb et al. 2008; Kapil et al. 2010), restore endothelial function (Stokes et al. 2009), and improve exercise performance (Vanhatalo et al. 2011; Murphy et al. 2012). These properties may be explained by the possible effect of $\mathrm{NO}_{3}{ }^{-}$present in beetroot juice in stimulating the endogenous synthesis of nitric oxide (NO).

Different $\mathrm{NO}_{3}{ }^{-}$contents of beetroot juice have been used in order to stimulate NO production, ranging from 5.2 to $22.5 \mathrm{mmol}$. Vanhatalo et al. (2010) observed a significant increase in NO production (evaluated indirectly by plasma nitrite $\left.\left[\mathrm{NO}_{2}{ }^{-}\right]\right)$after the consumption of $5.2 \mathrm{mmol}$ of $\mathrm{NO}_{3}{ }^{-}(500 \mathrm{~mL}$ of beetroot juice) by healthy subjects. Webb et al. (2008) and Lansley et al. (2011) observed an increase in NO production after the ingestion of 22.5 and $6.2 \mathrm{mmol}$ of $\mathrm{NO}_{3}{ }^{-}(500 \mathrm{~mL}$ of beetroot juice). Kapil et al. (2010) and Wylie et al. (2013) observed an increase in NO production after the ingestion of $5.5 \mathrm{mmol}\left(250 \mathrm{~mL}\right.$ of beetroot juice) and $16.8 \mathrm{mmol}$ of $\mathrm{NO}_{3}{ }^{-}$ ( $280 \mathrm{~mL}$ of beetroot juice), respectively. Cermak et al. (2012) observed an increase in NO production after the ingestion of $8.7 \mathrm{mmol}$ of $\mathrm{NO}_{3}^{-}$(140 $\mathrm{mL}$ of beetroot juice), respectively. 
However, only two of the aforementioned studies (Vanhatalo et al. 2010; Bailey et al. 2009) detailed information about how $\mathrm{NO}_{3}{ }^{-}$and $\mathrm{NO}_{2}{ }^{-}$contents from beetroot juice used in their interventions were analyzed. Analyzing $\mathrm{NO}_{3}{ }^{-}$and $\mathrm{NO}_{2}{ }^{-}$contents of different beetroot juices could be an important methodological strategy in order to guide researchers, because the physiological effects of beetroot may be directly related to $\mathrm{NO}_{3}{ }^{-}$content and not necessarily to the volume of beetroot juice consumed. Furthermore, there is a tendency to assume that the information on $\mathrm{NO}_{3}{ }^{-}$content given by commercial juice manufacturers (Webb et al. 2008; Kapil et al. 2010; Murphy et al. 2012; Wylie et al. 2013) is exact. However, juice manufacturer information on $\mathrm{NO}_{3}{ }^{-}$content may not necessarily reflect the real $\mathrm{NO}_{3}{ }^{-}$content of natural beetroot juice as given to volunteers during studies.

A variety of analytical methods to determine $\mathrm{NO}_{3}{ }^{-}$and $\mathrm{NO}_{2}^{-}$has already been performed for the analysis of these anions in biological samples, food, plants, water, agricultural products, and other matrices. These techniques include the Griess colorimetric assay, electrochemical detection, chemiluminescence, and capillary electrophoresis (Jimidar et al. 1995; Cheng and Tsang 1998; Siu and Henshall 1998, Tsikas 2007). However, these methods present disadvantages (Jobgen et al. 2007).

Since $\mathrm{NO}_{3}{ }^{-}$content may also vary according to agricultural management, landscape, and genetic factors (Tamme et al. 2006) - and there is a lack of available information about $\mathrm{NO}_{3}{ }^{-}$content in natural beetroot juice from different areasthe present study was conducted in order to evaluate the $\mathrm{NO}_{3}{ }^{-}$ and $\mathrm{NO}_{2}^{-}$contents in red beetroot in natura from different Brazilian regions by reversed-phase (RP) high-performance liquid chromatography (HPLC) method with fluorescence detection. The $\mathrm{NO}_{3}{ }^{-}$and $\mathrm{NO}_{2}{ }^{-}$contents in beetroot acquired in the USA were also evaluated.

\section{Material and Methods}

\section{Instruments and Chemicals}

\section{High-Performance Liquid Chromatography System}

The HPLC system consisted of a quaternary pump model LC20AD (Shimadzu ${ }^{\circledR}$, Tokyo, Japan), auto sampler model SIL10AF (Shimadzu ${ }^{\circledR}$, Tokyo, Japan), column oven model CTO20A (Shimadzu ${ }^{\circledR}$, Tokyo, Japan), and fluorescence detector model RF-20A (Shimadzu ${ }^{\circledR}$, Tokyo, Japan). A reversedphase $\mathrm{C} 18$ column $\left(3.5 \mu \mathrm{m}, 100 \times 4.6 \mathrm{~mm}\right.$, I.D., Kromasil ${ }^{\circledR}$, Bohus, Sweden) guarded by a reversed-phase C18 guard column $\left(5 \mu \mathrm{m}, 50 \times 4.6 \mathrm{~mm}\right.$, I.D., Nucleosil ${ }^{\circledR}$, Pennsylvania, USA) was used for separation of the analytical compounds.

\section{Chemicals}

All chemicals used in the present study were of analytical grade. Monobasic and dibasic sodium phosphate and HPLC grade methanol was purchased from Tedia (Tedia Company, INC., OH, USA). Purified and deionized water was obtained from a Milli-Q water purification system (Millipore, Molsheim, France) and was used to prepare the mobile phase solution, reagents, samples, and standards. Nitrate reductase (Aspergillus species, EC 1.6.6.2) and nicotinamide adenine dinucleotide phosphate (NADPH) were purchased from Roche (Roche Diagnostics, Mannheim, Germany). Sodium hydroxide $(\mathrm{NaOH})$ was obtained from Reagen (Ultrapure Chemicals of Brazil, Ltda., Rio de Janeiro, Brazil). Sodium $\mathrm{NO}_{3}{ }^{-}$and $\mathrm{NO}_{2}{ }^{-}$standards, 2.3-diaminonaphthalene (DAN), and flavin adenine dinucleotide (FAD) were obtained from Fluka (Sigma-Aldrich, São Paulo, Brazil). Hydrochloric acid (HCL) was obtained from Vetec (Vetec Quimica Fina, Ltda., Rio de Janeiro, Brazil).

\section{Sample Preparation for Analysis}

Three fresh red beetroots (B. vulgaris $\mathrm{L}$.) were acquired from five different markets ( 3 samples of each region $\times 5$ markets; $n=15$ ) located in the following regions of Brazil: (1) Northeast (State of Rio Grande do Norte: $5^{\circ} 47^{\prime} 07.3^{\prime \prime} \mathrm{S}, 35^{\circ} 12^{\prime} 14.6^{\prime \prime \prime} \mathrm{W}$ and State of Bahia: $11^{\circ} 51^{\prime} 16.5^{\prime \prime} \mathrm{S}, 40^{\circ} 50^{\prime} 19.3^{\prime \prime} \mathrm{W}$ ), (2) South (State of Santa Catarina: $27^{\circ} 35^{\prime} 45.8^{\prime \prime} \mathrm{S}, 48^{\circ} 32^{\prime} 51.9^{\prime \prime} \mathrm{W}$ ), and (3) Southeast (State of Rio de Janeiro: $22^{\circ} 51^{\prime} 55.8^{\prime \prime} \mathrm{S}, 43^{\circ} 13^{\prime}$ $34.1^{\prime \prime} \mathrm{W}$ and State of Minas Gerais: $17^{\circ} 43^{\prime} 56.6^{\prime \prime} \mathrm{S}, 44^{\circ} 35^{\prime} 00.7^{\prime \prime}$ W). Furthermore, three red beetroots of the same species were acquired in a New York supermarket (USA $-40^{\circ} 47^{\prime} 23.5^{\prime \prime} \mathrm{S}$, $73^{\circ} 57^{\prime} 13.0^{\prime \prime} \mathrm{W}$ ). Beetroots were produced in vegetable gardens near the region in order to supply the markets with fresh vegetables. In New York, the beetroots were cultivated in an urban farm and sold in a fresh vegetable market. The beetroots had no cracks, stains, bruises, and wet areas, which indicate deterioration. The vegetables were packed in black sealed plastic bags and stored at $5{ }^{\circ} \mathrm{C}$ for 2 days before being transported. These procedures conducted during vegetable purchase and storage aimed to avoid damage and cuts that could expose the inner tissues to microbial contamination, higher deterioration rates, and metabolism acceleration (Watada et al. 1996). The beetroots were weighed, cleaned with deionized water, and processed by using a centrifuge food processor (EC 700, Black \& Decker, São Paulo, Brazil) without adding any water. A mass of $0.350 \mathrm{~kg}$ of beetroot was sufficient to produce $100 \mathrm{~mL}$ of juice. The juice was diluted in 1:2000 and 1:100 ratios in order to analyze $\mathrm{NO}_{3}{ }^{-}$and $\mathrm{NO}_{2}{ }^{-}$, respectively. After dilution, each sample was filtered using a $0.22-\mu \mathrm{m}$ syringe filter (Syringe-driven Filter Unit, Millex ${ }^{\circledR}$, Merck Millipore Ltd., Carrigtwohill, Ireland). $\mathrm{NO}_{3}{ }^{-}$from the sample or standard (containing $\mathrm{NO}_{3}{ }^{-}$) was enzymatically 
converted to $\mathrm{NO}_{2}{ }^{-}$by an enzyme, $\mathrm{NO}_{3}{ }^{-}$reductase, in the presence of NADPH/FAD cofactors. Briefly, the HPLCfluorescence method is not capable of directly analyzing $\mathrm{NO}_{3}{ }^{-}$, thus, first, it is necessary to convert it to $\mathrm{NO}_{2}^{-}$. One hundred microliters of the sample (diluted and filtered) or $\mathrm{NO}_{3}{ }^{-}$standard solution $(0-2 \mu \mathrm{M})$ were treated by adding $10 \mu \mathrm{L}$ of $1 \mathrm{U} / \mathrm{ml} \mathrm{NO}_{3}{ }^{-}$reductase in the presence of $5 \mu \mathrm{L}$ of $120 \mu \mathrm{M}$ NADPH and $5 \mu \mathrm{L}$ of $2 \mu \mathrm{M}$ FAD. The conversion was carried out for $1 \mathrm{~h}$ at $24^{\circ} \mathrm{C}$ in a water bath (Nova Instruments, São Paulo, Brazil). Ten microliters of $316 \mu \mathrm{M}$ DAN in $0.62 \mathrm{M} \mathrm{HCl}$, that reacts rapidly with $\mathrm{NO}_{2}{ }^{-}$under acid conditions to form 2.3-naphthotriazole (NAT), a highly compound fluorescent, were added to the resulting $\mathrm{NO}_{2}^{-}$. After $10 \mathrm{~min}$, $\mathrm{NaOH}$ was added to stabilize the fluorescent compound to be analyzed by an HPLC system equipped with a SIL-10AF auto sampler.

\section{RP-HPLC-Fluorescence Analysis}

The mobile phase solution, which consisted of $15 \mathrm{mM}$ sodium phosphate buffer ( $\mathrm{pH} 7.5)$ and methanol $(50: 50 ; v / v)$, was allowed to pass through the HPLC column for 5 min until a stable baseline signal was obtained. The isocratic flow rate was $1.1 \mathrm{~mL} \cdot \mathrm{min}^{-1}$. When injections of the $\mathrm{NO}_{3}{ }^{-}$and $\mathrm{NO}_{2}{ }^{-}$ standard solutions (five each calibration curves with six points concentration) gave reproducible retention times and a peak area, each sample solution was then injected for analysis. The amount in microliters of solvents until reproducible retention times was of $38.5 \mathrm{~mL}$ for $\mathrm{NO}_{3}{ }^{-}$and $\mathrm{NO}_{2}^{-}$standard solution. The fluorescence was monitored with excitation at $375 \mathrm{~nm}$ and emission at $415 \mathrm{~nm}$. Retention times were approximately 3 min for $\mathrm{NO}_{3}{ }^{-}$and $\mathrm{NO}_{2}{ }^{-}$. The sample peaks were identified by comparison to the respective standard peaks. The amounts of $\mathrm{NO}_{3}{ }^{-}$and $\mathrm{NO}_{2}{ }^{-}$in each sample were calculated from the peak areas by using linear regression equations of the $\mathrm{NO}_{3}{ }^{-}$ and $\mathrm{NO}_{2}{ }^{-}$standard curves. The injection volume was $15 \mu \mathrm{L}$. At the end of the analyses, the RP-HPLC column was cleaned by running a $100 \%$ water and $100 \%$ methanol solution for $40 \mathrm{~min}$ for each solvent.

\section{Statistical Analyses}

A one-way analysis of variance (ANOVA) was used to identify differences in $\mathrm{NO}_{3}{ }^{-}$and $\mathrm{NO}_{2}{ }^{-}$contents between beetroots of different regions of Brazil and the USA. When a significant $F$ was found, additional post hoc tests with Bonferroni adjustments were performed. Statistical significance was set at the 0.05 level of confidence. All analyses were performed using a commercially available statistical package (IBM SPSS ${ }^{\circledR}$ Statistics version 20 for Windows, Chicago, IL, USA). The results regarding the $\mathrm{NO}_{3}{ }^{-}$and $\mathrm{NO}_{2}{ }^{-}$contents of all analyzed beetroot were converted from $\mu \mathrm{mol} . \mathrm{L}^{-1}$ to $\mathrm{mmol} . \mathrm{L}^{-1}$ of $\mathrm{NO}_{3}{ }^{-}$ and $\mathrm{NO}_{2}{ }^{-}$in beetroot juice in order to conduct comparisons with other studies published in the literature.

\section{Results}

\section{Linearity}

Figure 1 shows a very good linearity of $\mathrm{NO}_{2}^{-}$and $\mathrm{NO}_{3}{ }^{-}$determinations within the range of 0.125 to $4 \mu \mathrm{mol} . \mathrm{L}^{-1}$. Linearities were obtained over the tested concentration ranges from 0.125 to $4 \mu \mathrm{M}$ for both $\mathrm{NO}_{2}{ }^{-}$and $\mathrm{NO}_{3}{ }^{-}$. The linear regression equations were calculated as $y=2 E+06 x+119,441\left(R^{2}=\right.$ $0.9997)$ for the $\mathrm{NO}_{2}^{-}$and $y=2 E+06 x+111,643\left(R^{2}=0.9999\right)$ for $\mathrm{NO}_{3}^{-}$standard analysis.

\section{Limit of Detection}

The limit of detection for $\mathrm{NO}_{2}{ }^{-}$and $\mathrm{NO}_{3}{ }^{-}$was of $1.0 \times$ $10^{5} \mu \mathrm{mol} . \mathrm{L}^{-1}$, based on a signal-to-noise ratio of 4 when using the RF-20A fluorescence detector. The limit of detection of the present HPLC method for $\mathrm{NO}_{2}^{-}$and $\mathrm{NO}_{3}{ }^{-}$analyses is much higher than that of the Griess colorimetric assay (limit of detection of $2 \mu \mathrm{mol} . \mathrm{L}^{-1}$ ) (Jobgen et al. 2007). The limits of detection of the chemiluminescence method for $\mathrm{NO}_{2}{ }^{-}$and $\mathrm{NO}_{3}{ }^{-}$have been reported to be approximately $1.0 \times$ $10^{6} \mu \mathrm{mol} . \mathrm{L}^{-1}$ and $8.0 \times 10^{5} \mu \mathrm{mol} . \mathrm{L}^{-1}$, respectively (Tsikas 2007). Thus, this assay is less sensitive than the RP-HPLCfluorescence method for $\mathrm{NO}_{3}{ }^{-}$analysis.

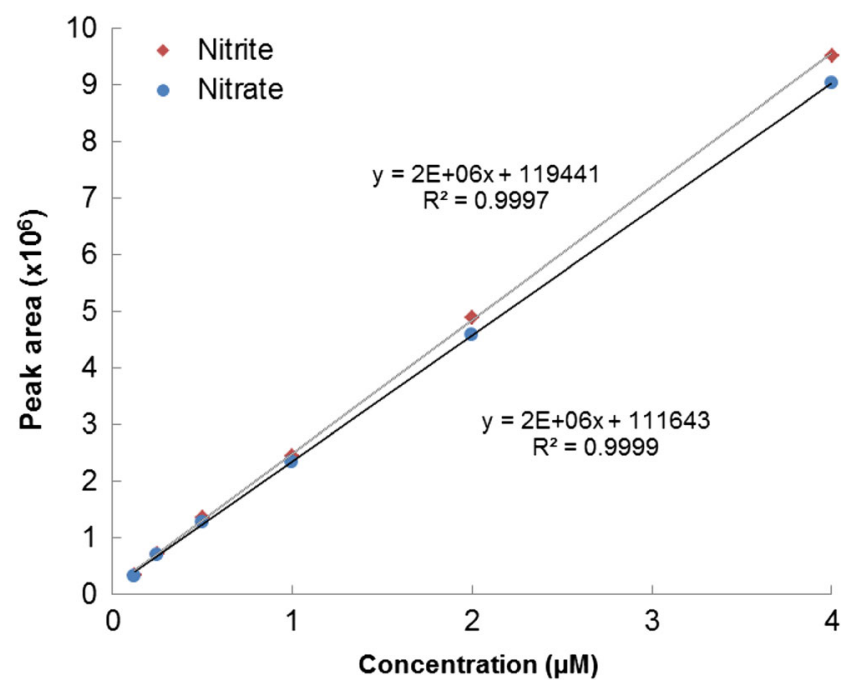

Fig. $1 \mathrm{NO}_{2}^{-}$and $\mathrm{NO}_{3}{ }^{-}$standard curves. The linear regression equations for the $\mathrm{NO}_{2}{ }^{-}$and $\mathrm{NO}_{3}{ }^{-}$standard curves were calculated as $y=2 E+06 x+$ $119,441\left(R^{2}=0.9997\right)$ and $y=2 E+06 x+111,643\left(R^{2}=0.9999\right)$, respectively; where $y$ is the value of peak area and $x$ is the value of the various concentrations of the standard solutions using the HPLCfluorescence method 


\section{Reproducibility}

In this paper, only intra-day and inter-day coefficient of variation $(\mathrm{CV}, \%)$ were considered to assess the reproducibility of the obtained values, which were calculated by the following formula: $\mathrm{CV}=[($ mean of $\mathrm{SD} /$ mean of replicates measurements)*100]. The $\mathrm{CV}$ ( $n=6$ replicates) for $\mathrm{NO}_{3}{ }^{-}$and $\mathrm{NO}_{2}{ }^{-}$ were 0.67 and $0.54 \%$ for intra-assays and 1.47 and $1.33 \%$ for inter-assays, respectively. Repeated trails all obtained CV values of less than $1.5 \%$, pointing out high degrees of reproducibility.

\section{$\mathrm{NO}_{3}{ }^{-}$and $\mathrm{NO}_{2}{ }^{-}$Contents in Beetroots}

Figure 2 shows a representative chromatogram of $\mathrm{NO}_{3}{ }^{-}$and $\mathrm{NO}_{2}{ }^{-}$contents in beetroot juice analyzed by RP-HPLCfluorescence.

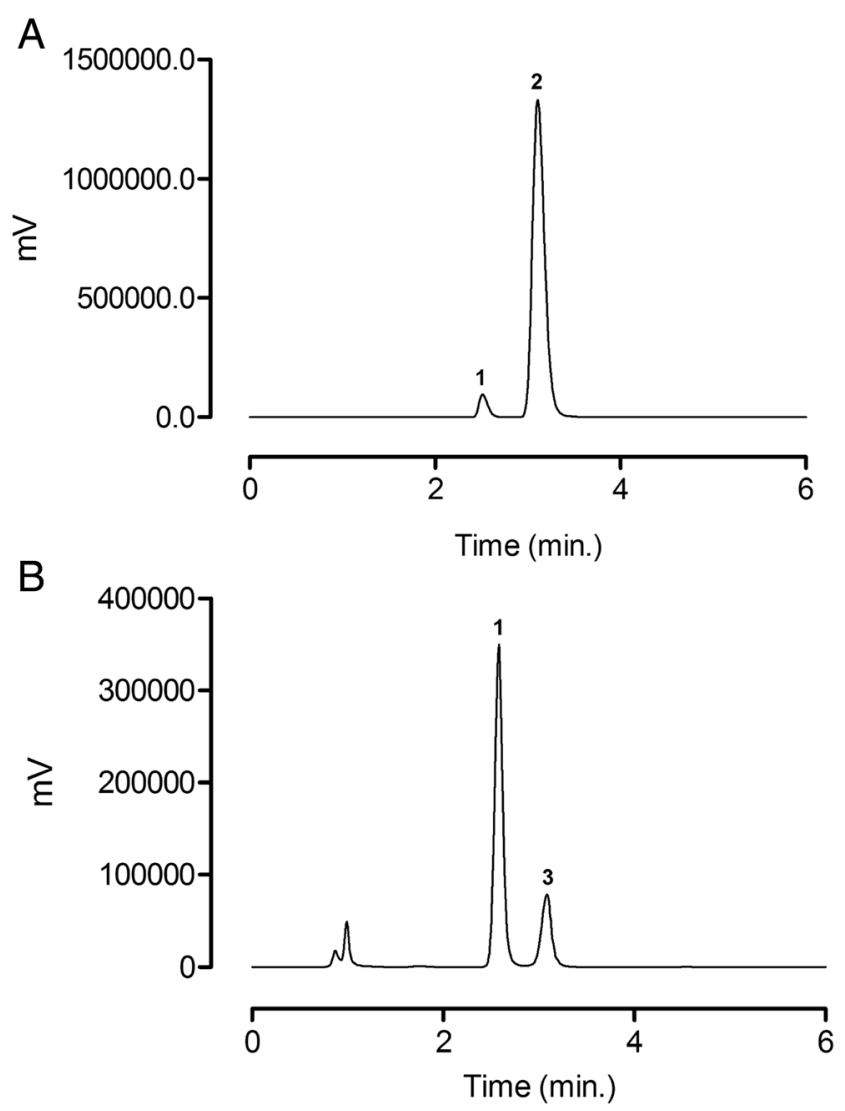

Fig. 2 Representative HPLC chromatogram of $\mathrm{NO}_{3}{ }^{-}$and $\mathrm{NO}_{2}{ }^{-}$analyses in beetroot juices. a Corresponds to a chromatogram analysis of $\mathrm{NO}_{3}{ }^{-}$in beetroot juices. $\mathrm{NO}_{3}{ }^{-}$was converted to $\mathrm{NO}_{2}{ }^{-}$by $\mathrm{NO}_{3}{ }^{-}$reductase enzyme. Then, $\mathrm{NO}_{2}^{-}$reacted with 2.3-diaminonaphthalene (DAN) to yield 2.3naphthotriazole (NAT) under acidic conditions. b Corresponds to a chromatogram analysis of the $\mathrm{NO}_{2}{ }^{-}$in beetroot juice. $\mathrm{NO}_{2}{ }^{-}$reacted with 2.3-diaminonaphthalene (DAN) to yield 2.3-naphthotriazole (NAT) under acidic conditions. The NAT $\left(\mathrm{NO}_{2}{ }^{-}\right.$-DAN) derivative was separated by RP-HPLC-fluorescence method: DAN (1); $\mathrm{NO}_{3}{ }^{-}$(2); $\mathrm{NO}_{2}{ }^{-}$ (3)
The $\mathrm{NO}_{3}{ }^{-}$content of beetroots from distinct geographical regions in Brazil and from Northern USA are compared in Table 1. Among the Brazilian beetroots, the beetroots from Rio de Janeiro showed the highest $\mathrm{NO}_{3}{ }^{-}$content. Beetroots from the Minas Gerais and Bahia states showed the lowest $\mathrm{NO}_{3}{ }^{-}$contents. Beetroot from Northern USA (31.2 \pm $0.010 \mathrm{mmol} . \mathrm{L}^{-1}$ ) showed the highest $\mathrm{NO}_{3}{ }^{-}$content when compared to Brazilian beetroots. The $\mathrm{NO}_{2}^{-}$contents of beetroots from distinct geographical regions were also estimated in Table 2. The $\mathrm{NO}_{2}^{-}$contents were higher in beetroots from the Rio Grande do Norte and Minas Gerais states. The beetroots from two locations in southeastern Brazil, Rio de Janeiro and Santa Catarina states, showed the lowest $\mathrm{NO}_{2}{ }^{-}$contents among the Brazilian beetroots. The beetroots from Northern USA also showed the highest $\mathrm{NO}_{2}{ }^{-}$content $(0.45 \pm$ $0.005 \mathrm{mmol} . \mathrm{L}^{-1}$ ) when compared to Brazilian beetroots.

\section{Discussion}

The beetroot belonging to the $B$. vulgaris $\mathrm{L}$. species is also considered a dietary source of $\mathrm{NO}_{3}{ }^{-}$(Santamaría 2006; Tamme et al. 2006). The $\mathrm{NO}_{3}{ }^{-}$present in this food matrix has been associated with improved cardiovascular function (Hobbs et al. 2012; Lidder and Webb 2013). The present study was designed with the purpose of evaluating the $\mathrm{NO}_{3}{ }^{-}$and $\mathrm{NO}_{2}^{-}$contents in Brazilian and US red beetroots by the RPHPLC method with fluorescence detection.

The main finding of the present study was that beetroots from Rio de Janeiro showed significantly high $\mathrm{NO}_{3}{ }^{-}$content when compared to beetroots from Rio Grande do Norte, Santa Catarina, Minas Gerais, and Bahia. Beetroots from Rio Grande do Norte showed significantly high $\mathrm{NO}_{2}{ }^{-}$content when compared to beetroots from Minas Gerais, Bahia, Rio

Table 1 Nitrate $\left(\mathrm{NO}_{3}{ }^{-}\right)$contents of beetroots acquired from different regions of Brazil and from the USA

\begin{tabular}{lc}
\hline Region & $\mathrm{mmol. \textrm {L } ^ { - 1 }}$ \\
\hline Northeastern Brazil & \\
$\quad$ Bahia & $5.74 \pm 0.033 \mathrm{e}$ \\
$\quad$ Rio Grande do Norte & $12.54 \pm 0.150 \mathrm{c}$ \\
Southeastern Brazil & \\
$\quad$ Minas Gerais & $6.46 \pm 0.057 \mathrm{e}$ \\
$\quad$ Rio de Janeiro & $17.1 \pm 0.020 \mathrm{~b}$ \\
Southern Brazil & \\
$\quad$ Santa Catarina & $10.0 \pm 0.056 \mathrm{~d}$ \\
Northern USA & \\
$\quad$ New York & $31.2 \pm 0.010 \mathrm{a}$ \\
\hline
\end{tabular}

The values are presented as means $\pm \mathrm{SD}$. Different letters denote statistical significance between the samples at $P<0.05$. Each juice sample (aliquot) was analyzed in quintuplicate 
Table 2 Nitrite $\left(\mathrm{NO}_{2}{ }^{-}\right)$ contents of beetroots acquired from different regions of Brazil and from the USA

\begin{tabular}{ll}
\hline Region & mmol. $\mathrm{L}^{-1}$ \\
\hline $\begin{array}{l}\text { Northeastern Brazil } \\
\quad \text { Bahia }\end{array}$ & $0.06 \pm 0.006 \mathrm{~d}$ \\
$\quad$ Rio Grande do Norte & $0.13 \pm 0.010 \mathrm{~b}$ \\
Southeastern Brazil & \\
$\quad$ Minas Gerais & $0.11 \pm 0.006 \mathrm{c}$ \\
$\quad$ Rio de Janeiro & $0.04 \pm 0.001 \mathrm{e}$ \\
Southern Brazil & \\
$\quad$ Santa Catarina & $0.04 \pm 0.006 \mathrm{e}$ \\
Northern USA & \\
$\quad$ New York & $0.45 \pm 0.005 \mathrm{a}$ \\
\hline
\end{tabular}

The values are presented as means $\pm \mathrm{SD}$. Different letters denote statistical significance between the samples at $P<0.05$

de Janeiro, and Santa Catarina. Beetroots from the USA showed higher $\mathrm{NO}_{3}{ }^{-}$and $\mathrm{NO}_{2}{ }^{-}$contents when compared to all beetroots acquired in Brazil.

Several factors affect the uptake and accumulation of $\mathrm{NO}_{3}{ }^{-}$ contents in vegetables (Habermeyer et al. 2015). Agricultural (type of cultivation, fertilization, use of herbicides, and availability of other nutrients) and environmental (atmospheric humidity, temperature, exposure to sunlight, and light intensity) factors are the factors that most affect $\mathrm{NO}_{3}{ }^{-}$content in beetroots (Santamaría 2006; Habermeyer et al. 2015). Originally from European and North African regions, the beetroot is a vegetable typical of temperate climates, which adapts well in temperatures between 10 and $20^{\circ} \mathrm{C}$ (Tullio et al. 2013). In the present study, the differences in $\mathrm{NO}_{3}{ }^{-}$content of beetroots from Rio de Janeiro compared with other Brazilian regions may be due to their cultivation during winter, when the climate is similar to that of the USA and Europe. Beetroot production in Rio de Janeiro in the winter period coincides with the greater availability of this vegetable in this state. With high temperatures $\left(>30^{\circ} \mathrm{C}\right)$, the state of Bahia has a tropical climate that is totally unsuitable for the cultivation of beetroot, which may be the reason that the beetroot from Bahia presented the lowest $\mathrm{NO}_{3}{ }^{-}$content compared to the other Brazilian beetroots. Although beetroots from Rio Grande do Norte presented the highest $\mathrm{NO}_{2}{ }^{-}$content when compared to the other Brazilian regions, the values of this anion were low in all the analyzed Brazilian beetroots. These results were already expected, since the beetroot is a vegetable that has a non-significant $\mathrm{NO}_{2}{ }^{-}$content (Pennington 1998; Tamme et al. 2006).

Besides the fact that the predominantly temperate climate in the USA is conducive to better beetroot development when compared to subtropical Brazil, a possible explanation for the differences in the $\mathrm{NO}_{3}{ }^{-}$and $\mathrm{NO}_{2}{ }^{-}$contents of beetroots from the USA and from different regions of Brazil may be due to agricultural factors. The use of nitrogen-based fertilizers also affects beetroot $\mathrm{NO}_{3}{ }^{-}$and $\mathrm{NO}_{2}{ }^{-}$contents (Pussemier et al. 2006). Thus, it is plausible that a more intensive usage of such fertilizers may explain the higher $\mathrm{NO}_{3}{ }^{-}$and $\mathrm{NO}_{2}^{-}$content from the USA when compared to beetroots from Brazil.

Recently, several intervention studies have been conducted using different amounts of beetroot (in juice form) for investigating the contribution of $\mathrm{NO}_{3}{ }^{-}$in NO synthesis (Webb et al. 2008; Bailey et al. 2009; Stokes et al. 2009; Kapil et al. 2010; Vanhatalo et al. 2011; Murphy et al. 2012; Wylie et al. 2013). However, most of these studies did not assess the $\mathrm{NO}_{3}{ }^{-}$and $\mathrm{NO}_{2}{ }^{-}$contents of the administered beetroot juices. The authors reported only the values based on information previously established by beetroot juice manufacturers. Fulford et al. (2013) administered $500 \mathrm{~mL}$ of beetroot juice supplied by James White Drinks Company Ltd. (Ipswich, UK). The authors reported that this amount of juice contained $5.1 \mathrm{mmol}$ (or $10.2 \mathrm{mmol} . \mathrm{L}^{-1}$ ) of $\mathrm{NO}_{3}{ }^{-}$. However, no information about how this content was evaluated was provided. Many other studies also did not provide this information (Webb et al. 2008; Kapil et al. 2010; Vanhatalo et al. 2010; Lansley et al. 2011; Cermak et al. 2012; Hobbs et al. 2012; Wylie et al. 2013).

The results of the present study demonstrate that the $\mathrm{NO}_{3}{ }^{-}$ contents in $1 \mathrm{~L}$ of juice of beetroot acquired in Rio de Janeiro and the USA were of $17.1 \pm 0.020 \mathrm{mmol}$ and $31.2 \pm$ $0.010 \mathrm{mmol}$, respectively. The $\mathrm{NO}_{3}{ }^{-}$contents in beetroot juice differ from those described by Webb et al. (2008), Bailey et al. (2009), Vanhatalo et al. (2010), and Kelly et al. (2013), which reported values of $45.0,11.2,10.4$, and $68.5 \mathrm{mmol} . \mathrm{L}^{-1}$, respectively. Kapil et al. (2010) also administered $250 \mathrm{~mL}$ of beetroot juice to nine healthy subjects, reporting that this amount contained $5.6 \mathrm{mmol}$ (or $22.4 \mathrm{mmol} . \mathrm{L}^{-1}$ ) of $\mathrm{NO}_{3}{ }^{-}$, and observed a significant reduction in systolic blood pressure. On the other hand, Gilchrist et al. (2013) also administered $250 \mathrm{~mL}$ of beetroot juice to 27 patients with type 2 diabetes mellitus, reporting a content of $7.5 \mathrm{mmol}$ (or $30 \mathrm{mmol} . \mathrm{L}^{-1}$ ) of $\mathrm{NO}_{3}^{-}$, and did not observe any reduction in blood pressure. The information provided by studies about $\mathrm{NO}_{3}{ }^{-}$content may not correspond to the actual content of this anion present in beetroot juices provided to volunteers. The possibility of such a discrepancy may be the reason why some studies observed different physiological effects following beetroot juice administration.

Furthermore, the discrepancies among the $\mathrm{NO}_{3}{ }^{-}$contents of the beetroot juices of the aforementioned studies show that it is crucial to precisely evaluate $\mathrm{NO}_{3}{ }^{-}$and $\mathrm{NO}_{2}{ }^{-}$contents in these tubers using the appropriate analytical techniques. Chemiluminescence analyses and Griess colorimetric assays are the most commonly used methods, but the chemiluminescence analysis shows certain disadvantages, such as bulky apparatus, low specificity and sensitivity, and inability to directly detect $\mathrm{NO}_{3}{ }^{-}$. Although the Griess reaction is simple, this sample amounts low sensitivity and specificity (Jobgen et al. 2007; Hetrick and Schoenfisch 2009). 


\section{Conclusion}

In conclusion, although beetroot juice has been consumed for its high $\mathrm{NO}_{3}{ }^{-}$content, the results of the present study demonstrate that beetroots from different regions of Brazil may vary in their $\mathrm{NO}_{3}{ }^{-}$and $\mathrm{NO}_{2}{ }^{-}$contents. Therefore, it is important that studies investigating beetroot juice analyze $\mathrm{NO}_{3}{ }^{-}$content by using the appropriate analytical techniques. The RPHPLC-fluorescence method is recommended to determine $\mathrm{NO}_{3}{ }^{-}$and $\mathrm{NO}_{2}{ }^{-}$in beetroots. The data from the present study represents a useful tool to encourage researchers to analyze the $\mathrm{NO}_{3}{ }^{-}$and $\mathrm{NO}_{2}{ }^{-}$contents in food that is administered with the intention of observing physiological and biochemical effects of these compounds on human health.

Acknowledgments The authors would thank Ricky Toledano for preparing the English version of the manuscript.

Compliance with Ethical Standards This article does not report any studies with human or animal subjects.

Conflicts of Interest Diego Baião declares that he has no conflict of interest. Carlos Conte-Junior declares that he has no conflict of interest. Vânia Paschoalin declares that he has no conflict of interest. Thiago Alvares declares that he has no conflict of interest.

Funding and Support Statement The Research Foundation of the State of Rio de Janeiro-FAPERJ by provided financial support for the study (process n ${ }^{\circ}$. E-26/111.297/2013 and E-26/110.309/2014).

Open Access This article is distributed under the terms of the Creative Commons Attribution 4.0 International License (http:// creativecommons.org/licenses/by/4.0/), which permits unrestricted use, distribution, and reproduction in any medium, provided you give appropriate credit to the original author(s) and the source, provide a link to the Creative Commons license, and indicate if changes were made.

\section{References}

Bailey SJ, Winyard P, Vanhatalo A, Blackwell JR, Dimenna FJ et al (2009) Dietary nitrate supplementation reduces the $\mathrm{O}_{2}$ cost of lowintensity exercise and enhances tolerance to high-intensity exercise in humans. J Appl Physiol 107:1144-1155. doi:10.1152/ japplphysiol.00722.2009

Cermak NM, Res P, Stinkens R, Lundberg JO, Gibala MJ et al (2012) No improvement in endurance performance after a single dose of beetroot juice. Int J Sport Nutr Exerc Metab 22:470-478, PMD: 23212319

Cheng CF, Tsang CW (1998) Simultaneous determination of nitrite, nitrate and ascorbic acid in canned vegetable juices by reverse-phase ion-interaction HPLC. Food Addit Contam 15:753-758. doi:10. 1080/02652039809374706

Fulford J, Winyard PG, Vanhatalo A, Bailey SJ, Blackwell JR et al (2013) Influence of dietary nitrate supplementation on human skeletal muscle metabolism and force production during maximum voluntary contractions. Pflugers Arch 465:517-528. doi:10.1007/s00424013-1220-5

Gilchrist M, Winyard PG, Aizawa K, Anning C, Shore A et al (2013) Effect of dietary nitrate on blood pressure, endothelial function, and insulin sensitivity in type 2 diabetes. Free Radic Biol Med 60:89-97. doi:10.1016/j.freeradbiomed.2013.01.024

Habermeyer M, Roth A, Guth S, Diel P, Engel KH et al (2015) Nitrate and nitrite in the diet: how to assess their benefit and risk for human health. Mol Nutr Food Res 59:106-128. doi:10.1002/mnfr. 201400286

Hetrick EM, Schoenfisch MH (2009) Analytical chemistry of nitric oxide. Annu Rev Anal Chem 2:409-433. doi:10.1146/annurevanchem-060908-155146

Hobbs DA, Kaffa N, George TW, Methven L, Lovegrove JA (2012) Blood pressure-lowering effects of beetroot juice and novel beetroot-enriched bread products in normotensive male subjects. Br J Nutr 108:2066-2074. doi:10.1017/S0007114512000190

Jimidar M, Hartmann C, Cousement N, Massart DL (1995) Determination of nitrate and nitrite in vegetables by capillary electrophoresis with indirect detection. J Chromatogr A 706:479-492. doi:10.1016/0021-9673(94)01290-U

Jobgen WS, Jobgen SC, Li H, Meininger CJ, Wu G (2007) Analysis of nitrite and nitrate in biological samples using high-performance liquid chromatography. J Chromatogr B Anal Technol Biomed Life Sci 851:71-82. doi:10.1016/j.jchromb.2006.07.018

Kapil V, Milsom AB, Okorie M, Maleki-Toyserkani S, Akram F et al (2010) Inorganic nitrate supplementation lowers blood pressure in humans: role for nitrite-derived NO. Hypertension 56:274-281. doi: 10.1161/HYPERTENSIONAHA.110.153536

Kelly J, Fulford J, Vanhatalo A, Blackwell JR, French O et al (2013) Effects of short-term dietary nitrate supplementation on blood pressure, $\mathrm{O}_{2}$ uptake kinetics, and muscle and cognitive function in older adults. Am J Physiol Regul Integr Comp Physiol 304:R73-R83. doi: 10.1152/ajpregu.00406.2012

Lansley KE, Winyard PG, Fulford J, Vanhatalo A, Bailey SJ et al (2011) Dietary nitrate supplementation reduces the $\mathrm{O}_{2}$ cost of walking and running: a placebo-controlled study. J Appl Physiol 110:591-600. doi:10.1152/japplphysiol.01070.2010

Lidder S, Webb AJ (2013) Vascular effects of dietary nitrate (as found in green leafy vegetables and beetroot) via the nitrate-nitrite-nitric oxide pathway. Br J Clin Pharmacol 75:677-696. doi:10.1111/j.13652125.2012.04420.x

Murphy M, Eliot K, Heuertz RM, Weiss E (2012) Whole beetroot consumption acutely improves running performance. J Acad Nutr Diet 112:548-552. doi:10.1016/j.jand.2011.12.002

Pennington JAT (1998) Dietary exposure models for nitrates and nitrites. Food Control 9:385-395. doi:10.1016/S0956-7135(98)00019-X

Pussemier L, Larondelle Y, Van Peteghem C, Huyghebaert A (2006) Chemical safety of conventionally and organically produced foodstuffs: a tentative comparison under Belgian conditions. Food Control 17:14-21. doi:10.1016/j.foodcont.2004.08.003

Santamaría P (2006) Nitrate in vegetables: toxicity, content, intake and EC regulation. J Sci Food Agric 86:10-17. doi:10.1002/jsfa.2351

Siu DC, Henshall A (1998) Ion chromatographic determination of nitrate and nitrite in meat products. J Chromatogr A 804:157-160. doi:10. 1016/S0021-9673(97)01245-4

Stokes KY, Dugas TR, Tang Y, Garg H, Guidry E et al (2009) Dietary nitrite prevents hypercholesterolemic microvascular inflammation and reverses endothelial dysfunction. Am J Physiol Heart Circ Physiol 296:H1281-H1288. doi:10.1152/ajpheart.01291.2008

Tamme T, Reinik M, Roasto M, Juhkam K, Tenno T et al (2006) Nitrates and nitrites in vegetables and vegetable-based products and their intakes by the Estonian population. Food Addit Contam 23:355361. doi:10.1080/02652030500482363

Tsikas D (2007) Analysis of nitrite and nitrate in biological fluids by assays based on griess reaction: appraisal of the griess reaction in the 1-arginine/nitric oxide area of research. J Chromatogr B Anal Technol Biomed Life Sci 851:51-70. doi:10.1016/j.jchromb.2006. 07.054 
Tullio JA, Otto RF, Boer A, Ohse S (2013) Beetroot cropping in natural and protected environments in summer. Rev Bras Eng Agríc Ambient 17:1074-1079. doi:10.1590/S1415-43662013001000008

Vanhatalo A, Bailey SJ, Blackwell JR, DiMenna FJ, Pavey TG et al (2010) Acute and chronic effects of dietary nitrate supplementation on blood pressure and the physiological responses to moderateintensity and incremental exercise. Am J Physiol Regul Integr Comp Physiol 299:1121-1131. doi:10.1152/ajpregu.00206.2010

Vanhatalo A, Fulford J, Bailey SJ, Balckwell JR, Winyard PG et al (2011) Dietary nitrate reduces muscle metabolic perturbation and improves exercise tolerance in hypoxia. J Physiol 589:5517-5528. doi:10. 1113/jphysiol.2011.216341
Watada AE, Ko NP, Minott DA (1996) Factors affecting quality of freshcut horticultural produce. Postharvest Biol Technol 9:115-193. doi: 10.1016/S0925-5214(96)00041-5

Webb AJ, Patel N, Loukogeorgakis S, Okorie M, Aboud Z et al (2008) Acute blood pressure lowering, vasoprotective, and antiplatelet properties of dietary nitrate via bioconversion to nitrite. Hypertension 51:784-790. doi:10.1161/hypertensionaha.107. 103523

Wylie LJ, Kelly J, Bailey SJ, Blackwell JR, Skiba PF et al (2013) Beetroot juice and exercise: pharmacodynamic and dose-response relationships. J Appl Physiol 115:325-336. doi:10.1152/ japplphysiol.00372.2013 